\title{
EVALUASI EFEKTIVITAS PENGGUNAAN DANA BANTUAN OPERASIONAL SEKOLAH (BOS) SEKOLAH MENENGAH KEJURUAN BIDANG KEAHLIAN BISNIS DAN MANAJEMEN DI KABUPATEN SLEMAN TAHUN 2014
}

\author{
EVALUATION OF THE USED OF SCHOOL OPERATIONAL ASSISTANCE FUND \\ (BOS) EFFECTIVENESS FOR STATE VOCATIONAL HIGH SCHOOL OF BUSINESS \\ AND MANAGEMENT IN SLEMAN 2014
}

Oleh:

Kaifan Nur Jannah

Pendidikan Akuntansi Universitas Negeri Yogyakarta kaifan.ifan@gmail.com

\begin{abstract}
Abstrak
Penelitian ini bertujuan untuk mengetahui efektivitas penggunaan dana BOS SMK Negeri Bidang Keahlian Bisnis dan Manajemen di Kabupaten Sleman Tahun 2014 yang ditinjau dari komponen konteks, input, proses, dan hasil/produk. Penelitian ini merupakan penelitian evaluasi kuantitatif dengan menggunakan model evaluasi CIPP Stufflebeam. Populasi dalam penelitian ini adalah seluruh warga SMK Negeri Bidang Keahlian Bisnis dan Manajemen di Kabupaten Sleman. Sampel dalam penelitian ini menggunakan teknik purposive sampling. Jumlah sampel dalam penelitian ini adalah 125 responden. Data dalam penelitian ini dikumpulkan dengan menggunakan kuesioner, wawancara, dokumentasi, serta observasi. Data dianalisis dengan menggunakan metode deskriptif kuantitatif $\mathrm{Z}$ score kemudian ditransformasikan ke dalam $\mathrm{T}$ score selanjutnya diverifikasi ke dalam prototype kuadran Glickman. Hasil analisis data diperoleh prototype variabel konteks, input, proses, dan produk dengan posisi CIPP $(++-+)$ pada kategori cukup efektif. Meskipun tergolong dalam kategori cukup efektif, namun terdapat kendala-kendala yang dihadapi dalam pelaksanaan program BOS baik dari variabel konteks, input, proses, maupun hasil. Untuk itu disarankan: (1) peningkatan pemahaman mengenai kebijakan program BOS, tujuan program BOS; (2) peningkatan kualitas sumber daya manusia, sosialisasi/pelatihan, organisasi/manajemen, dan dana operasional; (3) perencanaan program secara matang, penyaluran dana tepat waktu, pemanfaatan dana pada kebutuhan riil, monitoring dan evaluasi yang berkala dan objektif; (4) program peningkatan prestasi akademik dan non akademik bagi siswa.
\end{abstract}

Kata Kunci: Efektivitas, Model CIPP, Dana Bantuan Operasional Sekolah.

\section{Abstract}

This study is aimed to know the effectiveness of school operational assistance fund (BOS) for State Vocational High School of Business and Management in Sleman 2014. The effectiveness of school operational assistance fund (BOS) based on context,input, process, and product aspect. This study was categorized as an evaluatif-quantitative research. The population was all member of Vocational High School of Bisnis and Management in Sleman and based on purposive sampling, this research got 125 respondent. This study was quantitative evaluation which using The CIPP Stufflebeam model. The data was collected by questionnaire, interview, documentation and observation. Data was analized by quantitative descriptive. It used $Z$ score then transformed into $T$ score and converted into prototype quadrant of Glickman. The result showed the prototype variables context, input, process, and product were in the quite effective position of CIPP $(++-+)$ categories. Although this program was quite effective but there were obstacles faced in implementation of BOS program either in context, input, process, and product variables. So, this research also suggest some improvement in such areas for example: (1) to comprehending the policy about BOS, BOS program goals; (2) human resources quality; (3) program planning; (4) and academic and non academic achievement program. The other suggestions are School operational assistance fund distribution should be on time and in it use based 


\section{Jurnal Pendidikan Akuntansi Indonesia, Vol. XIV, No. 1, Tahun 2016}

Kaifan Nur Jannah

$1-9$

on priority needs. Government and school should conduct monitoring and evaluation objectively and continuity.

Keywords: Effectiveness, CIPP Model, School Operational Assistance Fund

\section{PENDAHULUAN}

Pendidikan memegang peran penting dalam kemajuan bangsa serta sumber daya manusia berkualitas yang mampu bersaing di tingkat lokal maupun tingkat global. Pendidikan merupakan hak bagi semua orang tanpa terkecuali. Hal tersebut menjadi tujuan dari Negara Republik Indonesia sejak merdeka yang tertuang dalam Pembukaan Undang-Undang Dasar Tahun 1945, UU No 20 Tahun 2003 tentang Sistem Pendidikan Nasional.

Dalam mewujudkan cita-cita pendidikan nasional, sampai saat ini Pemerintah masih dihadapkan dengan berbagai permasalahan, baik permasalahan internal maupun eksternal, seperti kualitas pendidik yang belum memenuhi standar mutu, sarana prasarana yang kurang memadai serta terbatasnya anggaran pendidikan yang disediakan oleh Pemerintah. Selain faktor internal, tantangan yang paling berat yang dihadapi Indonesia di era globalisasi adalah bagaimana menyiapkan sumber daya manusia yang cerdas, unggul, dan berdaya saing.

Dalam The Global Competitiveness Report 2014/2015 Indonesia menduduki peringkat ke 34 dari 144 negara dimana Malaysia pada peringkat ke 20 dan Thailand peringkat ke 31. Pada tahun 2014 Human Development Indext (HDI) Indonesia berada pada posisi 110 dari 188 negara.

Untuk memenuhi pendidikan yang berkualitas berdasarkan UU No 48 Tahun 2008 tentang Pendanaan Pendidikan bahwa pendidikan merupakan tanggung jawab bersama antara Pemerintah pusat, Pemerintah daerah, dan masyarakat. Perwujudan tanggung jawab Pemerintah terhadap pendanaan pendidikan melalui program Bantuan Operasional Sekolah (BOS).

Pada awal dilaksanakannya program BOS sasaran utamanya adalah pendidikan dasar guna mendukung wajib belajar 9 tahun. Seiring dengan pencapaian BOS pada pendidikan dasar, Pemerintah memperluas cakupan program BOS pada pendidikan menengah guna menyukseskan program Pendidikan Menengah Universal (PMU).

Menurut PP No 29 Tahun 1990, Pendidikan menengah kejuruan adalah pendidikan pada jenjang pendidikan menengah yang mengutamakan pengembangan siswa untuk melaksanakan jenis pekerjaan tertentu. Tujuan dari SMK menurut PP No 29 tahun 1990 yaitu: (1) mempersiapkan siswa untuk melanjutkan ke jenjang pendidikan yang lebih tinggi; (2) meningkatkan kemampuan siswa sebagai anggota masyarakat dalam mengadakan hubungan timbal balik dengan lingkungan sosial, budaya, dan sekitarnya; meningkatkan kemampuan siswa untuk dapat mengembangkan diri sejalan dengan pengembangan ilmu, teknologi, dan keterampilan; (4) menyiapkan siswa untuk memasuki lapangan kerja dan mengembangkan sikap profesional.

Berdasarkan Juknis BOS SMK 2014 BOS adalah program Pemerintah yang pada dasarnya adalah untuk penyediaan pendanaan biaya operasi nonpersonalia bagi satuan pendidikan dasar sebagai pelaksanaan program wajib belajar. BOS SMK memberikan dana langsung ke SMK baik Negeri maupun Swasta di seluruh Indonesia untuk membantu biaya operasional sekolah nonpersonalia.

Pusat Data dan Statistik Pendidikan, Kemendikbud (2011) menyatakan bahwa dari 4,2 lulusan SMK hanya \pm 3 juta lulusan yang melanjutkan ke jenjang pendidikan menengah. Dari fakta tersebut Pemerintah mencanangkan program Pendidikan Menengah Universal (PMU) pada tahun 2013 dengan salah satu tujuan yakni memberikan kesempatan bagi seluruh lapisan masyarakat terutama bagi kalangan yang tidak mampu secara ekonomi untuk mendapatkan layanan pendidikan menengah. Secara umum BOS bertujuan 
untuk meringankan beban masyarakat terhadap pembiayaan pendidikan, dan mewujudkan layanan pendidikan yang terjangkau dan bermutu bagi masyarakat.

Dengan adanya program BOS diharapkan banyak masyarakat dengan usia sekolah yang dapat melanjutkan pendidikannya hingga ke jenjang pendidikan menengah, dan tidak ada siswa yang putus sekolah. Namun fakta menunjukkan masih terdapat penduduk usia sekolah yang tidak melanjutkan karena permasalahan biaya pendidikan. Menurut Data Statistik Pendidikan 2014 siswa tidak melanjutkan sekolah yakni $27,75 \%$ karena masalah biaya.

Program BOS SMK dilakukan di seluruh Indonesia tanpa terkecuali di Kabupaten Sleman sejak tahun 2013. Berdasarkan hasil observasi siswa SMK Negeri Bidang Keahlian Bisnis dan Manajemen cukup banyak permintaannya. SMK Negeri Bisnis dan Manajemen juga mendapatkan dana BOS SMK. Namun demikian, masih terdapat permasalahan dalam pengelolaan dana BOS SMK diantaranya pengelola dana BOS masih kurang memadai, pemahaman pengelola dana BOS terhadap Juknis BOS SMK masih kurang, pertanggungjawaban sekolah kurang tegas, masih belum adanya evaluasi terhadap penggunaan dana BOS di SMK Negeri Bisnis dan Manajemen di Kabupaten Sleman. Oleh karena itu, diperlukan kajian mengenai efektivitas penggunaan dana BOS pada SMK Negeri Bisnis dan Manajemn di Kabupaten Sleman tahun 2014.

Efektivitas adalah pokok utama yang menyatakan berhasil tidaknya suatu organisasi dalam melaksanakan program atau kegiatan untuk mencapai tujuan dan mencapai targettargetnya yang ditentukan sebelumnya. Oleh karena itu, suatu organisasi dalam melaksanakan program dan kegiatan dikatakan efektif apabila tujuan atau sasaran yang dikehendaki dapat tercapai sesuai dengan rencana dan dapat memberikan dampak, hasil atau manfaat yang diinginkan. Menurut James L. Gibson dalam Agung (2005:107) kriteria atau ukuran efektivitas adalah kejelasan tujuan yang hendak dicapai, kejelasan strategi pencapaian tujuan, proses analisis dan perumusan kebijaksanaan yang mantap, perencanaan yang mantap, penyusunan program yang tepat, tersedianya sarana dan prasaran, pelaksanaan yang efektif dan efisien, sistem pengawasan dan pengendalian.

Rumusan masalah dari penelitian ini adalah bagaimana efektivitas penggunaan dana Bantuan Operasional Sekolah (BOS) Sekolah Menengah Kejuruan Bidang Keahlian Akuntansi di Kabupaten Sleman tahun 2014 ditinjau dari komponen konteks (context), input (input), proses (process), dan produk (product).

Tujuan dari penelitian ini adalah untuk mengetahui efektivitas penggunaan dana Bantuan Operasional Sekolah (BOS) Sekolah Menengah Kejuruan Bidang Keahlian Bisnis dan Manajemen di Kabupaten Sleman tahun 2014 ditinjau dari komponen konteks (context), input (input), proses (process), dan produk (product).

Hipotesis yang diajukan dalam penelitian ini adalah "Penggunaan dana Bantuan Operasional Sekolah (BOS) Sekolah Menengah Kejuruan Negeri Bidang Keahlian Bisnis dan Manajemen di Kabupaten Sleman tahun 2014 ditinjau dari komponen variabel konteks, input, proses, dan hasil termasuk dalam kategori cukup efektif'.

\section{METODE PENELITIAN Jenis Penelitian}

Penelitian ini merupakan studi empirik (expost facto) yaitu penelitian yang berhubungan dengan peristiwa yang telah terjadi dan peneliti tidakperlu memberikan perlakukan terhadap variabel yang diteliti (Sukardi, 2004:15). Secara metodologis penelitian ini termasuk penelitian evaluasi kuantitatif dengan menggunakan model CIPP (Context, Input, Process, Product) yang dikembangkan oleh Stufflebeam pada tahun 1971.

Menurut Bruce W. Tuckman (1985) dalam Sudjana (1990:3) evaluasi merupakan suatu proses untuk mengetahui/menguji apakah suatu kegiatan, proses (process) kegiatan, keluaran (output) suatu program 
telah sesuai dengan tujuan atau kriteria yang telah ditentukan. Pengertian evaluasi lebih dipertegas lagi dengan batasan sebagai proses memberikan atau menentukan nilai kepada objek tertentu berdasarkan suatu kriteria tertentu. Program merupakan kegiatan atau aktivitas yang dirancang untuk melaksanakan kebijakan dan melaksanakan untuk waktu yang tidak terbatas. Kebijakan tertentu bersifat umum dan untuk merealisasikan kebijakan disusun berbagai jenis program (Wirawan, 2012:16). Menurut Tyler (1950) dalam Suharsimi (2009:5) evaluasi program merupakan proses untuk mengetahui apakah tujuan pendidikan telah terealisasikan.

Model evaluasi CIPP adalah model evaluasi yang terdiri dari empat komponen evaluasi yaitu context, input,process, product. Menurut Suharsimi (2008:46-47) dijelaskan secara rinci evaluasi CIPP. Evaluasi konteks (context) adalah upaya untuk menggambarkan dan merinci lingkungan, kebutuhan yang tidak terpenuhi, populasi dan sampel yang dilayani, dan tujuan. Evaluasi masukan (input) merupakan evaluasi yang bertujuan menyediakan informasi untuk menentukan bagaimana menggunakan sumber daya yang tersedia dalam mencapai jutuan program. Evaluasi proses (process) menunjuk pada apa kegiatan yang dilakukan dalam program, siapa saja yang ditunjuk sebagai penanggung jawab program, kapan kegiatan akan selesai dilakukan. Evaluasi hasil (product) merupakan kumpulan deskripsi dan judgement outcomes dalam hubungannya dengan context, input, dan process terkait dengan perencanaan, pelaksanaan, dan keberhasilan program.

\section{Waktu dan Tempat Penelitian}

Penelitian ini dilakukan pada SMK Negeri Bidang Keahlian Bisnis dan Manajemen di Kabupaten Sleman yang terdiri atas SMK N 1 Godean, SMK N 1 Tempel, dan SMK N 1 Depok. Penelitian dilakukan mulai Bulan Desember 2015 sampai dengan bulan Februari 2016.

\section{Kriteria Evaluasi}

Pendeskripsian difokuskan pada pengukuran tingkat efektivitas pengelolaan dana Bantuan Operasional Sekolah pada Sekolah Menengah Kejuruan Negeri Bidang Keahlian Bisnis dan Manajemen di Kabupaten Sleman tahun 2014.

CIPP yang dimaksud dalam penelitian ini adalah sebagai berikut: Indikator dari variabel konteks meliputi (1) kebijakan terkait program BOS; (2) manfaat program BOS; (3) sasaran penerimaan dana BOS. Indikator dari variabel input meliputi (1) kondisi sumber daya manusia; (2) sarana dan prasarana; (3) organisasi dan manajemen. Indikator variabel proses meliputi (1) perencanaan penggunaan dana BOS; (2) pengambilan dana BOS; (3) penggunaan dana BOS; (4) monitoring dan evaluasi BOS; (5) pelaporan dan pertanggungjawaban dana BOS. Indikator variabel hasil meliputi (1) output: prestasi akademik, prestasi nonakademik; (2) outcome: minat melanjutkan ke perguruan tinggi favorit, minat untuk langsung bekerja.

\section{Populasi dan Sampel}

Populasi dalam penelitian ini adalah seluruh warga SMK Negeri Bidang Keahlian Bisnis dan Manajemen di Kabupaten Sleman yang terdiri atas SMK N 1 Depok, SMK N 1 Godean, dan SMK N 1 Tempel yang meliputi Kepala Sekolah, Wakil Kepala Sekolah, Bendahara Sekolah, Bendahara BOS, Kepala Tata Usaha, Kepala Perpustakaan, Guru, Karyawan, Komite Sekolah, dan Siswa.

Sampel adalah bagian dari jumlah dan karakteristik yang dimiliki oleh populasi tersebut (Sugiyono, 2011:120). Dalam penelitian ini penentuan sampel menggunakan teknik purposive sampling. Teknik sampling ini dilakukan dengan cara mengambil subyek bukan berdasarkan strata, random, wilayah tetapi didasarkan atas adanya tujuan tertentu (Agung, 2014:77). Pertimbangan yang digunakan dalam penelitian ini adalah sampel penelitian dapat mewakili setiap warga sekolah yang ada di SMK N Bidang Keahlian Bisnis dan Manajemen di Kabupaten Sleman.

Sampel dalam penelitian ini berjumlah 125 orang responden dipilih berdasarkan 
pertimbangan tertentu peneliti atau purposive sampling. Pertimbangan yang diajukan oleh peneliti adalah sampel penelitian dapat mewakili setiap warga sekolah. Sampel penelitian merupakan Kepala Sekolah, Wakil Kepala Sekolah, Bendahara Sekolah, Bendahara BOS, Guru, Bagian Tata Usaha, Karyawan, Siswa,serta Komite Sekolah dari tiga sekolah yaitu SMK N 1 Depok, SMK N 1 Tempel,dan SMK N 1 Godean.

\section{Data dan Analisis Data}

Teknik pengumpulan data yang digunakan adalah kuesioner, wawancara, dokumentasi, dan observasi. Metode utama dalam penelitian ini adalah metode kuesioner, sedangkan metode pelengkap/pendukung adalah metode wawancara, metode dokumentasi, dan metode observasi. Instrumen penelitian menggunakan instrumen kuesioner bagi responden guru dan karyawan, serta siswa.

Data dianalisis dengan statistik deskriptif dengan mengubah perolehan skor mentah menjadi $\mathrm{Z}$ skor dan ditransformasikan ke dalam $\mathrm{T}$ skor. Untuk menentukan tingkat efektivitas program, masing-masing variabel (konteks, input, proses, dan hasil) dianalisis dengan perimbangan kecenderungan arah $\mathrm{T}$ skor yang bernilai positif dan bernilai negatif dengan ketentuan jika $\mathrm{T}$ skor $>50=$ arah positif $(+)$ dan skor $\mathrm{T}$ skor $<50=$ arah negatif (-) yang selanjutnya diverivikasi ke dalam prototype efektivitas penggunaan dana Bantuan Operasional Sekolah (BOS) Sekolah Menengah Kejuruan Negeri Bidang Keahlian Bisnis dan Manajemen di Kabupaten Sleman tahun 2014 yang diadaptasi dari kuadran Glickman.

Analisis kuadran yang digunakan menggambarkan empat sisi keefektivan pelaksanaan program sebagai berikut:

1) Penggunaan dana BOS SMK efektif (kuadran I) dengan kondisi CIPP $\quad(+$ $+++)$.

2) Penggunaan dana BOS SMK cukup efektif (kuadran II) dengan kondisi variasi CIPP $(+++-),(++-+), \quad(+-++)$, $(-+++)$
3) Penggunaan dana BOS SMK kurang efektif (kuadran III) dengan kondisi variasi CIPP $(++--),(+--+), \quad(--$ $++),(-+-+),(+-+-),(-++-), \quad(+-$ $--),(-+--),(--+-),(---+)$.

4) Penggunaan dana BOS SMK sangat tidak efektif (kuadran IV) dengan kondisi CIPP ( - - - ).

\section{HASIL PENELITIAN DAN PEMBA- HASAN}

Hasil analisis data skor mentah dari masing-masing variabel dalam penelitian ini, disajikan dalam tabel berikut:

\begin{tabular}{|c|c|c|c|c|}
\hline \multirow{3}{*}{ 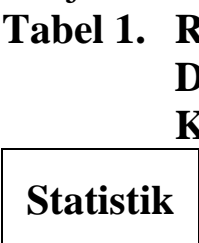 } & $\begin{array}{l}\text { angkuman } \\
\text { eskriptif } \\
\text { uesioner G }\end{array}$ & \multicolumn{2}{|c|}{$\begin{array}{l}\text { Data } \\
\text { Variabel } \\
\text { ru dan Kary }\end{array}$} & $\begin{array}{r}\text { Statistik } \\
\text { CIPP }\end{array}$ \\
\hline & \multicolumn{4}{|c|}{ Variabel } \\
\hline & Konteks & Input & Proses & Produk \\
\hline $\begin{array}{l}\text { Respon- } \\
\text { den }\end{array}$ & 65 & 65 & 65 & 65 \\
\hline $\begin{array}{l}\text { Mini- } \\
\text { mum }\end{array}$ & 21 & 22 & 43 & 13 \\
\hline $\begin{array}{l}\text { Maksi- } \\
\text { mum }\end{array}$ & 32 & 31 & 72 & 24 \\
\hline Mean & 26,82 & 26,52 & 58,26 & 18,83 \\
\hline Std. Dev. & 2,567 & 2,544 & 6,155 & 2,415 \\
\hline
\end{tabular}

Sumber : Data Primer Diolah, 2016

\begin{tabular}{llrr} 
Tabel 2. & Rangkuman & Data & Statistik \\
Deskriptif & Variabel & CIP \\
Kuesioner Siswa & & \\
\hline
\end{tabular}

\begin{tabular}{|l|c|c|c|}
\hline \multirow{2}{*}{ Statistik } & \multicolumn{3}{|c|}{ Variabel } \\
\cline { 2 - 4 } & Konteks & Input & Produk \\
\hline Responden & 60 & 60 & 60 \\
\hline Minimum & 13 & 14 & 9 \\
\hline Maksimum & 20 & 20 & 16 \\
\hline Mean & 16,88 & 16,98 & 12,73 \\
\hline Std. Dev. & 2,034 & 1,645 & 1,351 \\
\hline
\end{tabular}

Sumber : Data Primer Diolah, 2016

Berdasarkan analisis deskripif yang telah dilakukan, data pada variabel konteks menurut guru dan karyawan menunjukkan skor minimum sebesar 21, skor maksimum 32, rata-rata 26,82, dan standar deviasi 2,567. Berdasarkan kuesioner siswa variabel konteks menunjukkan skor minimum 13, skor maksimum 20, rata-rata 16,88 , dan standar 
deviasi 2,034. Pelaksanaan program dari variabel konteks pada umumnya termasuk dalam kategori "cukup efektif".

Data variabel input menurut guru dan karyawan menunjukkan skor minimum 22, skor maksimum 31, rata-rata 26,52, standar deviasi 2,544. Berdasarkan kuesioner siswa menunjukkan skor minimum 14, skor maksimum 20, rata-rata 16,98 , dan standar deviasi 1,645. Pelaksanaan program dari variabel input pada umumnya termasuk dalam kategori "cukup efektif".

Data variabel proses menurut guru dan karyawan menunjukkan skor minimum 43, skor maksimum 72 , rata-rata 58,26 , dan standar deviasi 6,155. Pelaksanaan program jika ditinjau dari variabel proses pada umumnya termasuk dalam kategori "cukup efektif".

Sedangkan, pada variabel hasil menurut guru dan karyawan menunjukkan skor minimum 12 , skor maksimum 24 , rata-rata 18,83, dan standar deviasi 2,415. Pelaksanaan program dari variabel hasil pada umumnya termasuk dalam kategori "cukup efektif”.

Tabel 3. Rangkuman Hasil Analisis Variabel Konteks, Input, Proses, dan Hasil tentang Efektivitas Penggunaan Dana BOS SMK Negeri Bidang Keahlian Bisnis dan Manajemen di Kabupaten Sleman Tahun 2014

\begin{tabular}{|c|c|c|c|c|c|c|c|}
\hline \multirow[b]{2}{*}{ No } & \multirow[b]{2}{*}{$\begin{array}{l}\mathbf{V} \\
\mathbf{a} \\
\mathbf{r} .\end{array}$} & \multicolumn{6}{|c|}{ Frekuensi } \\
\hline & & $\mathbf{f}(-)$ & $\begin{array}{l}\mathbf{f}(-) \\
\%\end{array}$ & $\mathbf{f}(+)$ & $\begin{array}{c}\mathbf{f}(+) \\
\%\end{array}$ & $\begin{array}{c}\mathrm{Hs} \\
\mathrm{l}\end{array}$ & $\begin{array}{c}\text { Ket./ } \\
\text { Posisi } \\
\text { (CIPP) } \\
\text { pada } \\
\text { kuadran } \\
\text { Glickma } \\
\text { n }\end{array}$ \\
\hline 1 & $\mathrm{C}$ & 54 & 43,3 & 71 & 56,8 & + & $(++-$ \\
\hline 2 & I & 53 & 42,4 & 72 & 57,6 & + & $+)$ \\
\hline 3 & $\mathrm{P}$ & 40 & 61,5 & 25 & 38,4 & - & Posisi II \\
\hline 4 & $\mathrm{P}$ & 62 & 49,6 & 63 & 50,4 & + & $\begin{array}{l}\text { (Cukup } \\
\text { Efektif) }\end{array}$ \\
\hline
\end{tabular}

Dari tabel di atas, dapat dijelaskan bahwa efektivitas penggunaan dana Bantuan
Operasional Sekolah pada Sekolah Menengah Kejuruan Negeri Bidang Keahlian Bisnis dan Manajemen di Kabupaten Sleman pada tahun 2014 menunjukkan kategori cukup efektif dengan posisi CIPP positif-positif-negatifpositif $(++-+)$.

Hasil analisis terhadap variabel konteks dengan skor $\mathrm{T}$ menunjukkan bahwa variabel konteks berada pada kategori positif/efektif. Perbandingan persentase kategori positif dan negatif pada variabel konteks efektifitas penggunaan dana Bantuan Operasional Sekolah SMK Negeri Bidang Keahlian Bisnis dan Manajemen di Kabupaten Sleman tahun 2014 sebanyak $56,80 \%: 43,29 \%$, atau sebanyak 71 responden berkategori positif berbanding 54 responden berkategori negatif. Indikator evaluasi pada variabel konteks terdiri atas kebijakan terkait program BOS, manfaat program BOS, sasaran program BOS.

Pada variabel input, skor $\mathrm{T}$ menunjukkan kategori positif/efekif. Perbandingan persentase kategori positif dan negatif variabel input efektivitas penggunaan dana Bantuan Operasional Sekolah SMK Negeri Bidang Keahlian Bisnis dan Manajemen di Kabupaten Sleman tahun 2014 sebanyak $57,60 \%$ : $42,40 \%$, atau sebanyak 72 responden berkategori positif berbanding 53 responden berkategori negatif. Indikator evaluasi pada variabel input terdiri atas kondisi sumber daya manusia, kondisi sarana dan prasarana dan organisasi dan manajemen.

Ditinjau dari variabel proses, skor $\mathrm{T}$ menunjukkan hasil pada kategori negatif/tidak efektif. Perbandingan persentase kategori positif dan negatif variabel proses efektivitas penggunaan dana Bantuan Operasional Sekolah SMK Negeri Bidang Keahlian Bisnis dan Manajemen di Kabupaten Sleman tahun 2014 sebesar 38,46\%: 61,54\%, atau sebanyak 25 responden berkategori positif berbanding dengan 40 responden berkategori negatif. Dari lima indikator yang dilibatkan dalam pengukuran variabel produk, yakni perencanaan penggunaan dana BOS, pengambilan dana $\mathrm{BOS}$, penggunaan dana BOS monitoring dan evaluasi BOS, pelaporan dan pertanggungjawaban dana BOS semua 
indikator memberikan kecenderungan skor $\mathrm{T}$ yang bernilai negatif. Pertama indikator perencanaan program Batuan Operasional Sekolah (BOS), perbandingan kategori positif terhadap negatif sebanyak 32,31\%:67,69\%, atau sebanyak 21 responden berkategori positif sedangkan 41 responden berkategori negatif. Pada indikator ini menunjukkan bahwa perencanaan penggunaan dana BOS pada SMK Negeri Bidang Keahlian Bisnis dan Manajemen di Kabupaten Sleman tahun 2014 dalam pelaksanaannya masih belum efektif.

Kedua, indikator pengambilan dana BOS menunjukkan perbandingan kategori positif dan kategori negatif sebanyak $36,92 \%$ : $63,08 \%$ atau sebanyak 28 responden berkategori positif dan 41 responden berkategori negatif. Indikator ini menunjukkan bahwa pengambilan dana BOS masih belum efektif. Dana BOS SMK tahun 2014 disalurkan oleh Pemerintah pusat kepada sekolah secara bertahap yakni 3 kali penerimaan. Pada periode I penerimaan dana BOS diterima pada tanggal 7 Februari 2014, sedangkan pada periode II diterima secara bertahap yang pertama pada tanggal 24 Juli 2014 dan yang kedua pada tanggal 17 November 2014.

Ketiga, indikator penggunaan dana BOS menunjukkan perbandingan kategori positif dan negatif sebanyak $41,54 \%: 58,48 \%$, atau 27 responden berkategori positif dan 38 responden berkategori negatif. Dalam indikator penggunaan dana BOS menunjukkan kecenderungan yang negatif, yang berarti penggunaan dana BOS pada SMK Negeri Bidang Keahlian Bisnis dan Manajemen di Kabupaten Sleman tahun 2014 masih kurang efektif. Pemahaman pengelola dana BOS di sekolah terhadap Juknis BOS SMK 2014 yang masih kurang, serta belum adanya pelatihan pengelolaan dana BOS SMK bagi para pengelola dana BOS menyebabkan pengelolaan dana yang kurang efektif.

Keempat, Indikator monitoring dan evaluasi program BOS menunjukkan perbandingan kategori positif dan negatif sebanyak $41,54 \%: 58,46 \%$, atau sebanyak 27 responden berkategori positif dan 38 responden berkategori negatif. Sama seperti dengan indikator sebelumnya, dalam indikator monitoring dan evaluasi program BOS masih kurang efektif.

Kelima, indikator pelaporan dan pertanggungjawaban dana BOS menunjukkan perbandingan kategori positif dan negatif sebanyak $\quad 38,46 \%: 61,54 \%$, atau sebanyak 25 responden berkategori positif dan 40 responden berkategori negatif. Sehingga indikator pelaporan dan pertanggungjawaban dana BOS memberikan kecenderungan kategori negatif yang artinya pertanggungjawaban dana BOS kurang efektif.

Hasil analisis deskriptif menunjukkan perbandingan variabel input efektivitas penggunaan dana BOS SMK Negeri Bidang Keahlian Bisnis dan Manajemen di Kabupaten Sleman tahun 2014 yakni kategori positif dan kategori negatif sebesar 50,40\% : 49,60\%, atau sebanyak 63 responden berkategori positif dan 62 responden berkategori negatif. Pada variabel hasil terdiri dari 2 indikator yakni output: prestasi akademik, prestasi nonakademik input: minat melanjutkan ke perguruan tinggi favorit, minat untuk langsung bekerja.

Kendala-kendala yang ditemukan dalam pelaksanaan program Bantuan Operasional Sekolah Menengah Kejuruan Negeri Bidang Keahlian Bisnis dan Manajemen di Kabupaten Sleman tahun 2014 serta alternatif pemecahannya. Pada variabel konteks secara umum terdapat kendala dalam beberapa aspek seperti pemahaman terhadap kebijakan pendidikan terkait dengan program BOS, tujuan dari dilaksanakannya program BOS SMK perlu dipahami secara utuh sehingga dapat tercapai, kebutuhan sekolah dan harapan masyarakat yang belum terealisasi secara maksimal. Alternatif pemecahan diantaranya dilakukan sosialisasi mengenai program BOS SMK secara bertahap dan berkelanjutan bagi para pengelola BOS terkait dengan program BOS dan tujuan dari program BOS SMK. Selain itu mengubah paradigma masyarakat bahwa pendidikan merupakan tanggung jawab bersama antara Pemerintah, sekolah, dan juga 
masyarakat bukan hanya Pemerintah dan sekolah saja.

Pada variabel input, keterbatasan sumber daya manusia pengelola BOS di beberapa sekolah berpengaruh terhadap pengelolaan dana BOS, keterbatasan pemahaman pengelola BOS terhadap Juknis BOS SMK menjadikan kendala dalam pembuatan laporan, penggunaan dana, dan penyaluran dana BOS. Alternatif solusinya yakni diadakannya pelatihan khusus pengelolaan dana BOS yang berkelanjutan sehingga pengelola dana BOS mampu secara maksimal mengelola dana BOS sesuai dengan mekanisme yang diminta oleh Pemerintah pusat. Partisipasi oleh masyarakat dalam pengembangan Bussiness Center diharapkan dapat mampu membantu pendanaan operasional sekolah.

Pada variabel proses, tidak semua dewan guru mengetahui mengenai program BOS, perencanaan pengelolaan dana BOS yang kurang maksimal. Solusinya, perencanaan program dibuat secara matang dan melibatkan semua pihak yang berkepentingan termasuk dewan guru dan komite sekolah.

Pada variabel hasil, masih adanya siswa yang putus sekolah karena alasan menikah dan bekerja. Solusinya, pendampingan oleh orang tua dan guru serta pemahaman mengenai pentingnya pendidikan.

\section{SIMPULAN DAN SARAN \\ Simpulan}

Berdasarkan analisis data dan temuan, dapat disimpulkan sebagai berikut.

Efektivitas penggunaan dana Bantuan Operasional Sekolah (BOS) SMK Negeri Bidang Keahlian Bisnis dan Manajemen di Kabupaten Sleman tahun 2014 ditinjau dari komponen variabel konteks tergolong dalam kategori cukup efektif.

Efektivitas penggunaan dana Bantuan Operasional Sekolah (BOS) SMK Negeri Bidang Keahlian Bisnis dan Manajemen di Kabupaten Sleman tahun 2014 ditinjau dari komponen variabel input tergolong dalam kategori cukup efektif.

Efektivitas penggunaan dana Bantuan Operasional Sekolah (BOS) SMK Negeri
Bidang Keahlian Bisnis dan Manajemen di Kabupaten Sleman tahun 2014 dilihat dari komponen variabel proses bila ditinjau berdasarkan skor $\mathrm{T}$ menunjukkan arah skor negatif. Yang berarti komponen variabel proses dalam penggunaan dana BOS SMK Negeri Bidang Keahlian Bisnis dan Manajemen di Kabupaten Sleman tahun 2014 belum efektif.

Efektivitas penggunaan dana Bantuan Operasional Sekolah (BOS) SMK Negeri Bidang Keahlian Bisnis dan Manajemen di Kabupaten Sleman tahun 2014 ditinjau dari komponen variabel hasil tergolong dalam kategori cukup efektif.

Bila dianalisis secara keseluruhan berdasarkan temuan-temuan di atas, dapat disimpulkan bahwa efektivitas penggunaan dana Bantuan Operasional Sekolah (BOS) SMK Negeri Bidang Keahlian Bisnis dan Manajemen di Kabupaten Sleman tahun 2014 tergolong dalam kategori cukup efektif dilihat dari variabel konteks, input, proses, dan produk $(++-+)$. Dengan demikian seluruh indikator yang dilibatkan dalam variabel konteks tergolong cukup efektif, variabel input cukup efektif, variabel proses tidak efektif, dan variabel hasil cukup efektif.

\section{Saran}

Saran terkait variabel konteks, input, proses, dan produk/hasil.

Pemerintah pusat (Direktorat Pembinaan SMK, Dirjen Pendidikan Menengah) hendaknya membuat kebijakan yang tepat dan proporsional untuk program BOS SMK serta melakukan sosialisasi program dan mekanisme pelaksanaan BOS secara terusmenerus melalui Dinas Pendidikan Pemuda dan Olahraga Provinsi. Dinas Pendidikan Pemuda dan Olahraga Provinsi melaksanakan koordinasi dengan Dinas Pendidikan Pemuda dan Olahraga Kabupaten/Kota. Dinas Pendidikan Pemuda dan Olahraga Kabupaten/Kota mensosialisasikan program BOS serta melaksanakan seluruh kebijakan Pemerintah pusat maupun Pemerintah provinsi. Pemerintah kabupaten dan lembaga pendidikan bekerja sama dalam mensosialisasikan kepada masyarakat 
mengenai paradigma berpikir bahwa pendidikan bukan hanya tanggung jawab Pemerintah dan sekolah saja tetapi juga tanggung jawab masyarakat. Sekolah bersama komite sekolah mensosialisasikan kepada orang tua siswa bahwa dengan adanya BOS bukan berarti biaya pendidikan gratis. Sekolah diharapkan dapat memberitahukan mengenai laporan penggunaan dana BOS untuk apa saja agar orang tua mengetahui bagaimana pengelolaan dana BOS di sekolah.

Dinas Pendidikan Pemuda dan Olahraga baik Provinsi maupun Kabupaten hendaknya mengadakan pelatihan-pelatihan dalam bentuk bimbingan teknis bagi sumber daya manusia khususnya pengelola BOS agar dapat bekerja secara efektif serta efisien, sehingga mampu melaksanakan tugasnya sesuai dengan juknis dengan benar. Pengelola dana BOS perlu ditingkatkan melalui pendidikan lanjut agar pengelola BOS memahami petunjuk pelaksanaan dan petunjuk teknis tentang BOS serta mampu memahami uraian tugas pengelola BOS mengingat pelaporan BOS sangat terinci. Pengembangan Bussiness Center secara maksimal guna mendorong peningkatan kualitas kegiatan operasional sekolah.

Pemerintah Pusat (Direktorat Pembinaan SMK, Direktorat Jendral Pendidikan Menengah) diharapkan membuat format yang lebih sederhana dan memudahkan pengelola dana BOS dalam pengelolaan administrasi dan pelaporan. Dilakukan monitoring dan evaluasi secara berkala dan teratur oleh Dinas Pendidikan dan Olahraga Kabupaten/Kota dalam pengelolaan dana BOS. Sekolah hendaknya merencanakan program dengan baik sesuai dengan skala prioritas kebutuhan. Penyaluran dana tepat watktu dan pemanfaatan dana terfokus pada kebutuhan riil dan skala prioritas.

Sekolah diharapkan membuat program dan kegiatan yang mendorong dan mendukung peningkatan kualitas prestasi akademis maupun non akademis siswa guna mencegah siswa drop out dan mencegah penurunan kualitas siswa.

\section{DARTAR PUSTAKA}

A. A Gede Agung. (2014). Buku Ajar Metodologi Penelitian Pendidikan. Malang: Aditya Media Publishing.

Agung Kurniawan, (2005). Transformasi Pelayanan

Publik. Yogyakarta:Pembaharuan.

Badan Pusat Statistik. (2014). Statistik Pendidikan Indonesia 2014.

Direktorat Pembinaan Sekolah Menengah Kejuruan. (2014). Petunjuk Teknis 2014 Bantuan Operasional Sekolah (BOS) SMK.

Human Development Report 2015. UNDP.

Nana Sudjana. (1990). Penilaian Hasil Proses Belajar Mengajar. Bandung: PT Remaja Rosdakarya Offset.

Schwab, Klaus. (2015). The Global Competitiveness Report 2014-2015. World Economic Forum .

Sekretaris Negara Republik Indonesia. (2008). Undang-Undang Republik Indonesia Nomor 48 Tahun 2008 tentang Pendanaan Pendidikan.

Sekretaris Negara Republik Indonesia. (1990). Undang-Undang Nomor 29 Tahun 1990 tentang Pendidikan Menengah.

Suharsimi Arikunto. (2009). Dasar-Dasar Evaluasi Pendidikan. Jakarta: Bumi Aksara

Suharsimi Arikunto. (2008). Evaluasi Program Penidikan: Pedoman Praktis bagi Mahasiswa dan Praktisi Pendidikan.Sugiyono. (2011). Metode Penelitian Kombinasi (Mixed Method). Bandung: Alfabeta.

Sukardi. (2004). Metodologi Penelitian Pendidikan (Kompetensi dan Praktiknya). Jakarta: Bumi Aksara.

Wirawan. (2012). Evaluasi Kinerja Sumber Daya Manusia, Teori Aplikasi dan Penelitian. Jakarta: Salemba Empat. 